\title{
White rings on the threatened coral, Acropora palmata, associated with foraging activity of the honeycomb cowfish, Acanthostracion polygonius (Ostraciidae)
}

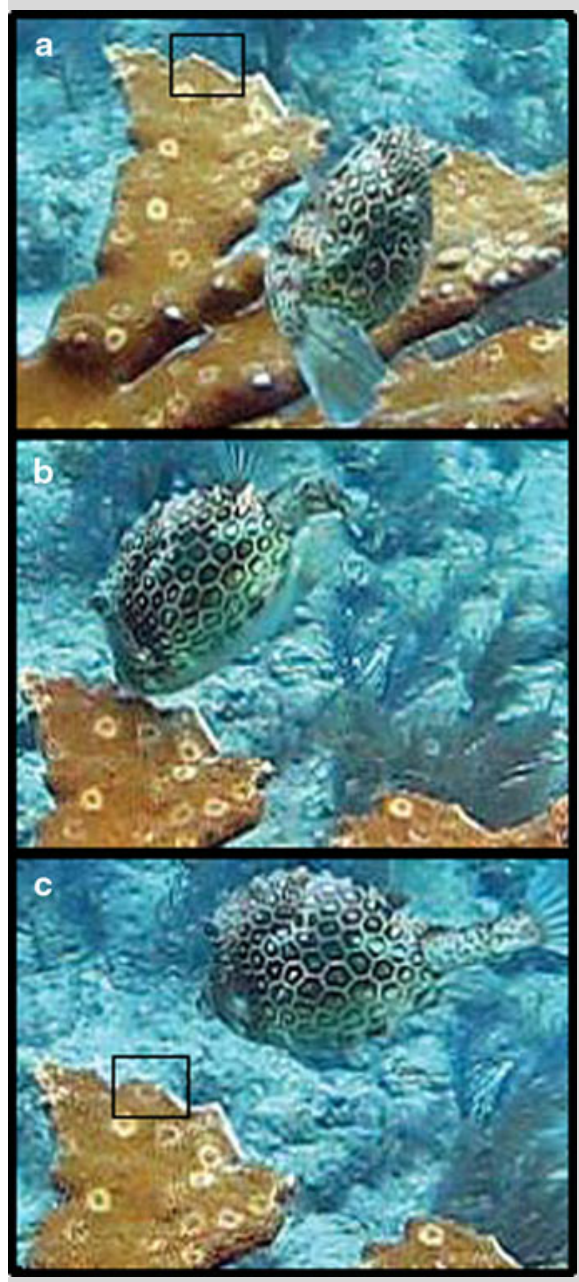

Fig. 1 Time series photographs of the cowfish, $A$. polygonius, foraging on a colony of $A$. palmata, a before the lesion was created (designated by black box), $\mathbf{b}$ in the act of creating the lesion, and $\mathbf{c}$ after the lesion was created (designated by black box)

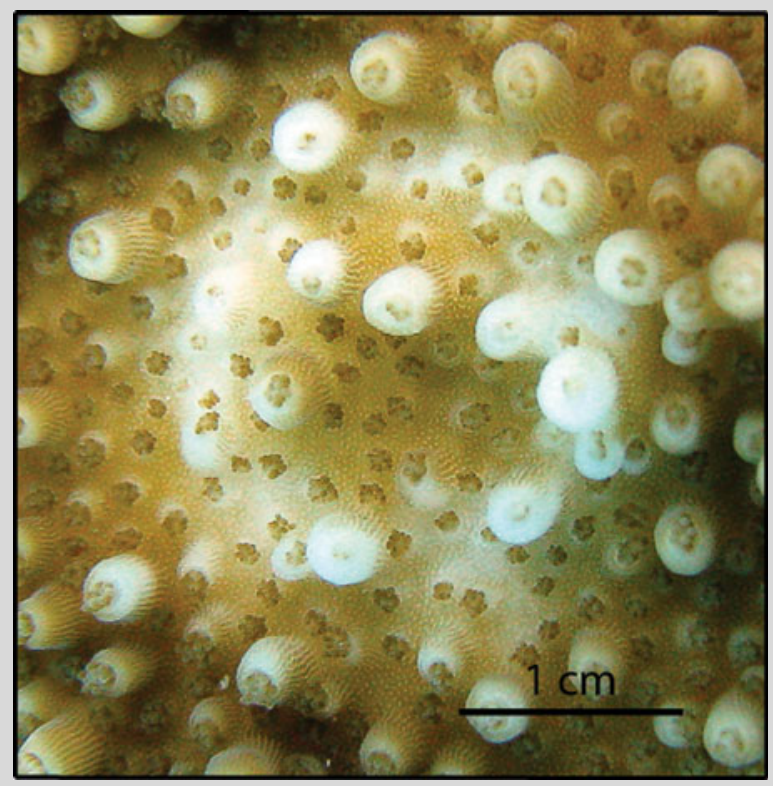

Fig. 2 Photograph of annular lesion created by A. polygonius on the coral, A. palmata
Monitoring of the threatened Caribbean coral, Acropora palmata, in the upper Florida Keys, USA, since 2002, has revealed annular lesions of unknown origin. On September 13, 2012, a honeycomb cowfish (Acanthostracion polygonius) was observed creating annular lesions on A. palmata colonies at Molasses Reef in the Florida Keys (Fig. 1; video in Electronic Supplemental Material). A. polygonius typically preys on tunicates, alcyonarians, sponges, small crustaceans and gastropods (Randall 1967), and is not known to be a corallivore (Cole et al. 2008). To our knowledge, this is the first report of this species creating lesions on $A$. palmata.

Lesions created by $A$. polygonius are distinct from other known fish bites

(Bruckner 2007). They appear as a white ring with apparently healthy, intact tissue in the center, and are approximately $2 \mathrm{~cm}$ in diameter (Fig. 2). The ring appearance results from partial removal of tissue from the sides of the corallites and coenosteum, leaving polyps within the ring intact. There is no apparent mechanical damage to the corallites. As healing progresses, the ring gradually becomes a ring of pale tissue until zooxanthellae are recovered. Lesions heal rapidly (less than 6 weeks) and do not contribute to significant losses of live tissue. It is uncertain whether the fish is actively feeding on the coral tissue or the lesion is a by-product of the fish's foraging behavior. Although these lesions are rare, affecting $6 \pm 4 \%$ (mean $\pm \mathrm{SD}$ ) of colonies in the Florida Keys, their occurrence is typically clustered, affecting nearly $100 \%$ of colonies at some sites. Of our 24 monitoring sites in Florida, colonies are consistently affected at three sites, while rings were rare to absent at the remaining sites. Through A. palmata monitoring in other locations: Curaçao (since 2006), Navassa (since 2006), British Virgin Islands (2006-2007), Puerto Rico (2007-2009), and US Virgin Islands (2007-2009), we have observed these annular lesions to have a similar patchy occurrence but lower average prevalence than in the Florida Keys.

\section{References}

Bruckner A (2007) Field guide to western Atlantic coral diseases and other causes of coral mortality. NOAA, UNEP-WCMC, PADI

Cole AJ, Pratchett MS, Jones GP (2008) Diversity and functional importance of coral-feeding fishes on tropical coral reefs. Fish Fish 9:286-307 Randall JE (1967) Food habits of reef fishes of the West Indies. Stud Trop Oceanog 5:665-847

Electronic supplementary material The online version of this article (doi:10.1007/s00338-013-1024-2) contains supplementary material, which is available to authorized users.

D. E. Williams · A. J. Bright $(\bowtie)$

Cooperative Institute for Marine and Atmospheric Studies, University of Miami, 4600 Rickenbacker Cswy, Miami, FL 33149, USA

e-mail: allan.bright@noaa.gov

D. E. Williams · A. J. Bright

National Marine Fisheries Service, Southeast Fisheries Science Center, Miami, FL, USA

Received: 17 December 2012/Accepted: 27 February 2013/Published online: 16 March 2013

Coral Reefs (2013) 32:651

(C) Springer-Verlag Berlin Heidelberg 2013 